\title{
PROPOSAL FOR CALCULATING THE BEARING CAPACITY OF SCREW DISPLACEMENT PILES IN NON-COHESIVE SOILS BASED ON CPT RESULTS
}

\author{
ADAM KRASIŃSKI \\ Gdańsk University of Technology, Department of Geotechnics, Geology and Maritime Engineering, \\ ul. Narutowicza 11/12, 80-233 Gdańsk, Poland, e-mail: akra@pg.gda.pl
}

\begin{abstract}
Screw displacement pile technology is relatively new and is still being developed. A specific characteristic of those piles is their very considerable influence on soil properties during the installation, which renders classical bearing capacity calculation methods insufficient. Some methods for calculating the bearing capacity of screw displacement piles have already been presented in literature, for example, by Bustmante and Gianesselli [2], [3], Van Impe [17], [18], Maertens and Huybrechts [15], Ne Smith [16] as well as Basu and Prezzi [1]. This paper proposes a new method of calculating the bearing capacity of screw displacement piles in non-cohesive soil which is based on CPT results. It has been devised as a result of research project No. N N506 432936 [11], carried out in 2009-2011. At 6 experimental sites screw displacement pile static loading tests were carried out together with CPTU tests of the subsoil. The results allowed us to establish soil resistances along the shaft $t_{s}$ as well as under the pile base $q_{b}$ and their correlations to the CPT soil cone resistances $q_{c}$. Two approaches, both adapted to the general guidelines of Eurocode 7 (EC7) [20], were proposed: a classical approach and the second approach with load transfer functions application.
\end{abstract}

\section{LIST OF SYMBOLS}

$A_{b} \quad-$ pile base surface,

$A_{s} \quad-$ pile shaft surface,

$D \quad$ - pile diameter,

$M_{T} \quad-\quad$ torque during the penetration of pile auger into the soil,

$q_{b} \quad-\quad$ unit soil resistance under pile base,

$Q_{b} \quad-\quad$ pile base resistance,

$q_{b ; u l t}-$ ultimate unit soil resistance under pile base,

$q_{c} \quad-$ unit soil resistance under CPT cone,

$Q_{c} \quad-$ total load on pile head,

$q_{c b} \quad-\quad$ unit CPT cone resistance equivalent for pile base,

$q_{c s} \quad-$ unit CPT cone resistance equivalent for pile shaft,

$Q_{N} \quad-\quad$ part of total pile load carried by bearing soil layers,

$Q_{s} \quad$ - pile shaft resistance in bearing soil layers,

$Q_{T n} \quad$ - pile shaft resistance in upper weak soil layers,

$R_{c ; c a l}$ - total bearing capacity of pile,

$R_{b ; c a l}$ - bearing capacity of pile base,

$R_{s ; c a l}$ - bearing capacity of pile shaft,

$R_{c ; d}$ - computational total bearing capacity of pile,

$R_{b ; d} \quad$ - computational bearing capacity of pile base,

$R_{s ; d} \quad-$ computational bearing capacity of pile shaft, 


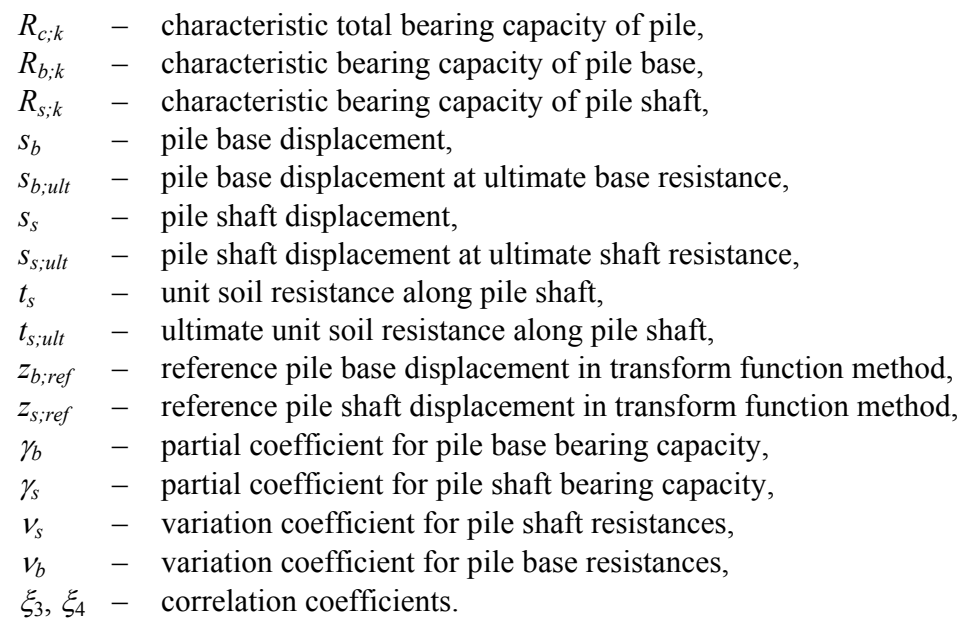

\section{INTRODUCTION}

The research of screw displacement piles was conducted at six experimental sites near Gdańsk. The soil structure comprised weak organic soils (peat and mud) in the upper layers and load bearing saturated fine and medium grain sands at the base. The experimental sites were selected in association with several road building projects.

At each of the sites three or four either $D=360 \mathrm{~mm}$ or $D=400 \mathrm{~mm}$ screw displacement piles were prepared for tests. Depending on the contractor and site, the applied piles were either CMC (Controlled Modulus Columns), SDP (Screw Displacement Piles) or SDC (Screw Displacement Columns). These columns and piles are very similar to one another and can be generally termed "Omega" system piles.

Before test piles were installed, CPTU subsoil tests were carried out at each of the six sites.

Most of the screw piles were equipped with specialist measurement instrumentation to gauge the axial force distribution along the shaft during successive static load tests. The instrumentation comprised a chain of five vibrating wire extensometers to measure the length changes of particular pile shaft sections. The principles of how this particular instrumentation works have been described by the author in other papers [13], [14].

A total of 21 piles were used at the experimental sites and the results from 16 pile tests were considered reliable enough to be used in further analysis. A detailed description of the screw pile tests, the results of these tests and their subsequent interpretation is found in the author's other works [8]-[12].

Figures 1 and 2 present the test results of just one of the piles. Figure 1 shows pile shaft axial force distributions during the application of loads, a graph of $q_{c}$ resistances taken before and after pile installation, and a graph of torque readings $M_{T}$ taken during 
the turning of the auger. The axial force distributions presented in Fig. 1 allowed us to define the load displacement component values $Q_{c}, Q_{N}, Q_{s}, Q_{b}$ and $Q_{T n}$, presented as a pile displacement graph in Fig. 2.

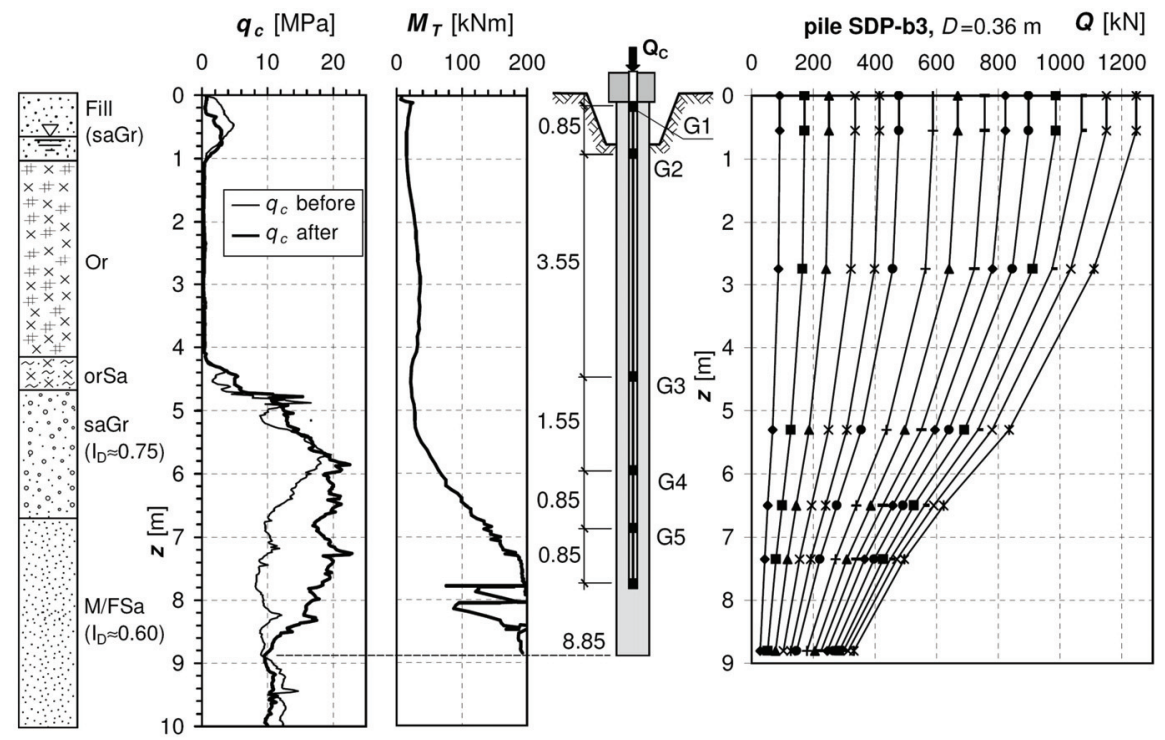

Fig. 1. Example of SDP-b3 pile load bearing capacity results

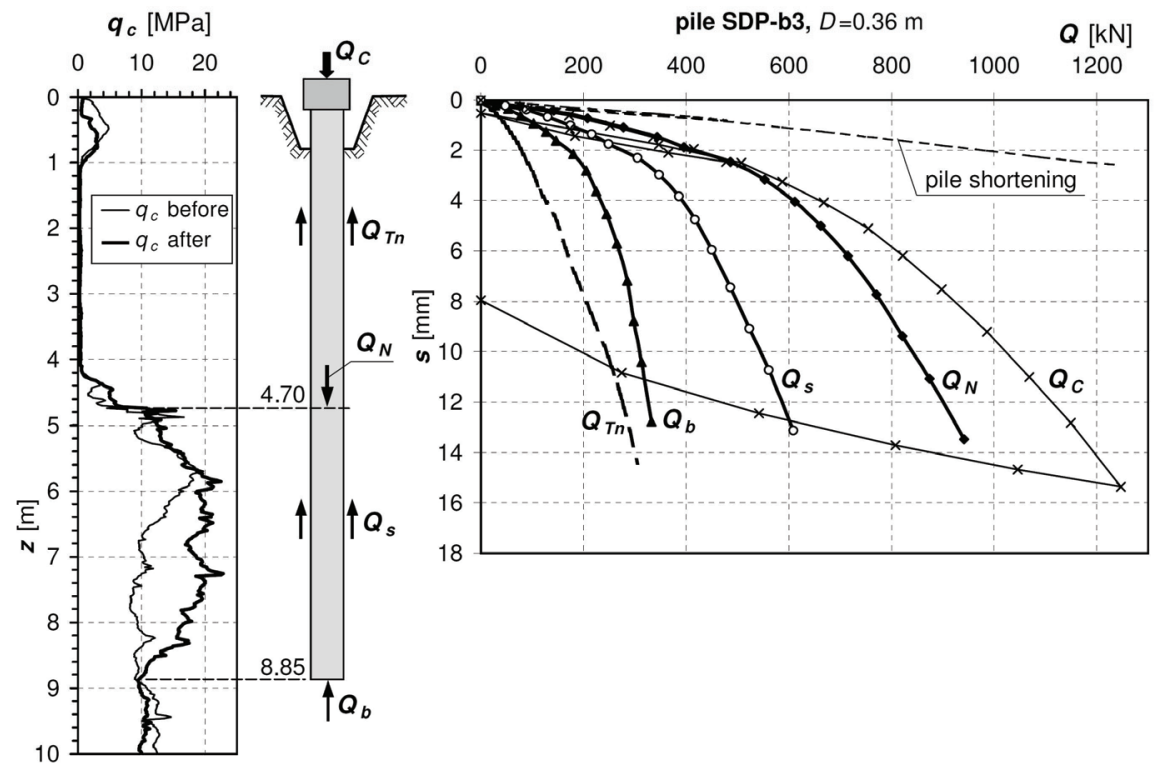

Fig. 2. Graphs of forces carried by the soil along an SDP-b3 pile shaft and under its base 


\section{PILE TEST RESULTS}

One of the fundamental objectives of conducting field tests on screw displacement piles was to establish the unit resistance values of soil friction along the pile shaft $t_{s}$ and soil resistance at the pile base $q_{b}$ in non-cohesive soils and compare them to $q_{c}$ soil resistance under a CPT cone.

Figure 3 presents graphs of $t_{s}$ and $q_{b}$ soil resistance values based on the displacement results of the 16 screw piles under investigation. In most cases, resistance $t_{s}$ is between $110 \mathrm{kPa}$ and $150 \mathrm{kPa}$, while $q_{b}$ ranges from $2500 \mathrm{kPa}$ to over $4000 \mathrm{kPa}$. Differences between resistance values result chiefly from the difference in the mechanical properties of the soil at various experimental sites. The averaged $q_{c}$ resistance values varied from approximately $8 \div 10 \mathrm{MPa}$ to over $25 \mathrm{MPa}$.
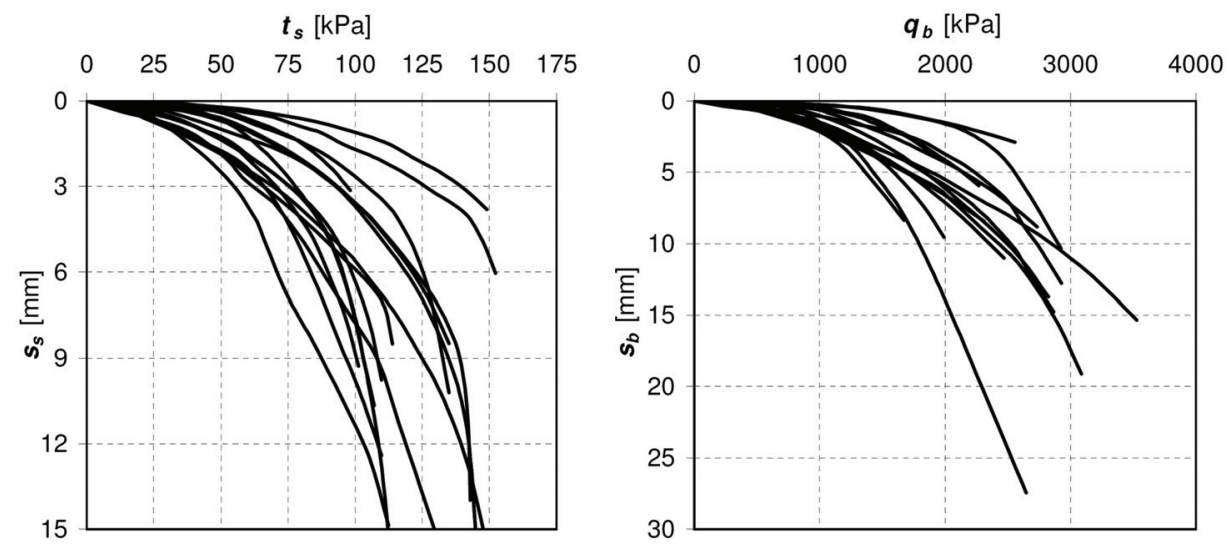

Fig. 3. Graphs of unit resistances $t_{s}$ and $q_{b}$
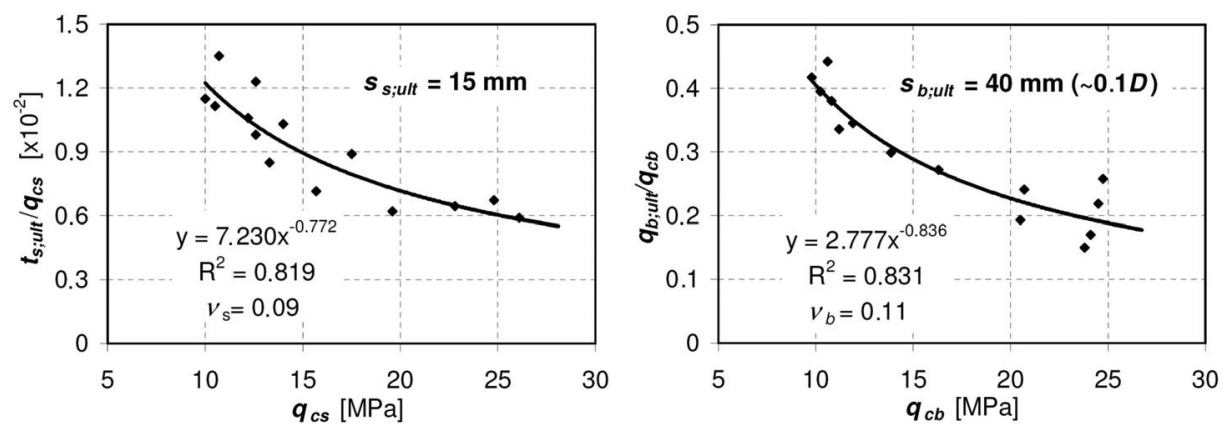

Fig. 4. Dependence of $t_{s ; g r} / q_{c s}$ and $q_{c ; g r} / q_{c b}$ on CPT $q_{c s}$ and $q_{c b}$ resistance values

Figure 4 presents ultimate relative resistances $t_{s ; u l t} / q_{c s}$ and $q_{b ; u l t} / q_{c b}$ in relation to CPT resistances $q_{c s}$ and $q_{c b}$. The ultimate values $t_{s ; u l t}$ were assumed as $t_{s}$ at displace- 
ment $s_{s ; u l t}=15 \mathrm{~mm}$, and $q_{b ; u l t}$ as $q_{b}$ resistances at displacement $s_{b ; u l t}=40 \mathrm{~mm}(\sim 0.1 D)$. Most of the plots in Fig. 3 were extrapolated to the ultimate displacements $s_{s ; u l t}$ and $s_{b ; \text {; ll }}$. The value of $q_{c s}$ was taken to be the average value of $q_{c}$ along the entire shaft length of the load bearing soil, whereas $q_{c b}$ was taken to be the average value of the depth interval from $-D$ to $+2 D$ ( $D=$ pile diameter) measured from the pile base. The points plotted in coordinate system in Fig. 4 are arranged as power functions. Figure 4 also presents the values of variation coefficients $v_{s}$ and $v_{b}$.

\section{PROPOSED METHOD OF CALCULATING SCREW DISPLACEMENT PILE BEARING CAPACITY}

\subsection{CLASSICAL APPROACH}

\section{Bearing capacity of pile}

For the proposed method the author has adopted the classical formula for calculating the bearing capacity $R_{c ; c a l}$ of screw piles, recommended also by EC7

$$
R_{c ; c a l}=R_{b ; c a l}+R_{s ; c a l}=A_{b} \cdot q_{b ; u l t}+\sum_{i} A_{s ; i} \cdot t_{s ; u l t, i}
$$

where:

$R_{b ; c a l}, R_{s ; c a l}-$ pile base and pile shaft bearing capacity,

$A_{b}, A_{s ; i}$ - base surface and shaft surface in section $i$,

$q_{b ; u l t}, t_{s ; u l t, i}$ - soil unit resistances under the pile base and along the pile shaft in section $i$.

Surfaces $A_{b}$ and $A_{s}$ should be calculated in relation to the nominal diameter of the pile formed.

The values of $q_{b ; u l t}$ and $t_{s ; u l t}$ are calculated on the basis of the empirical data in Fig. 4, which have been converted into absolute soil resistance values. After taking into account the variation coefficients $v_{s}=0.10$ and $v_{b}=0.11$ the following formulas for calculating ultimate resistances $t_{s ; u l t}$ and $q_{b ; u l t}$ were obtained

$$
\begin{aligned}
& t_{s ; u l t ; i}=65 \cdot\left(\frac{q_{c s ; i}}{q_{r e f}}\right)^{0,23}[\mathrm{kPa}], \\
& q_{b ; \text { ult }}=2475 \cdot\left(\frac{q_{c b}}{q_{r e f}}\right)^{0,16}[\mathrm{kPa}],
\end{aligned}
$$

where $q_{\text {ref }}$ is the reference stress, taken to be $1 \mathrm{MPa}$.

In the above formulas (2) and (3) values $q_{c s, i}$ and $q_{c b}$ should be given in MPa and moreover they should fulfil the following criteria 


$$
q_{c s} \in(5 \div 25) \quad[\mathrm{MPa}] \text { and } q_{c b} \in(5 \div 30) \quad[\mathrm{MPa}]
$$

\section{Correlation coefficients $\xi_{3}$ and $\xi_{4}$}

EC7 recommends the use of $\xi_{3}$ and $\xi_{4}$ correlation coefficients, which base bearing capacity of piles calculations to the number $n$ of subsoil profiles. Table 1 shows the recommended coefficients. The values cited are marginally lower than those recommended by EC7. They have been divided by 1.1 on account of the more regular way in which screw displacement piles work in the soil when compared with other pile technologies.

Table 1

Correlation coefficient values $\xi_{3}$ and $\xi_{4}$ (n-number of profiles under study)

\begin{tabular}{|c|c|c|c|c|c|c|c|}
\hline$\xi$ for $n=$ & 1 & 2 & 3 & 4 & 5 & 7 & 10 \\
\hline$\xi_{3}$ & 1.3 & 1.25 & 1.21 & 1.19 & 1.17 & 1.15 & 1.13 \\
\hline$\xi_{4}$ & 1.25 & 1.15 & 1.12 & 1,09 & 1.05 & 1.0 & 1.0 \\
\hline
\end{tabular}

In the method proposed, which is based on CPT subsoil test results, the number $n$ is understood as the number of CPT carried out in the foundation area of a given building.

The characteristic bearing capacities of the pile base and shaft are calculated in accordance with the recommended EC7 procedure

$$
R_{b ; k}=\min \left\{\frac{\left(R_{b ; c a l}\right)_{\text {mean }}}{\xi_{3}} ; \frac{\left(R_{b ; c a l}\right)_{\min }}{\xi_{4}}\right\} \text { and } R_{s ; k}=\min \left\{\frac{\left(R_{s ; c a l}\right)_{\text {mean }}}{\xi_{3}} ; \frac{\left(R_{s ; c a l}\right)_{\min }}{\xi_{4}}\right\} .
$$

\section{Partial coefficients $\gamma_{s}$ and $\gamma_{b}$}

Coefficients $\gamma_{s}$ and $\gamma_{b}$ serve to convert the characteristic load bearing capacities of piles to computational values according to the formula

$$
R_{c ; d}=R_{b ; d}+R_{s ; d}=\frac{R_{b ; k}}{\gamma_{b}}+\frac{R_{s ; k}}{\gamma_{s}}
$$

According to EC7, the characteristic values of pile bearing capacities mean the ultimate load bearing. In the method proposed, coefficient values $\gamma_{s}$ and $\gamma_{b}$ are regarded to be the settlement criterion. Experience and calculation analysis show that for most constructions the safe settlement of individual piles oscillates in the region of $10 \mathrm{~mm}$. The way of determining coefficients $\gamma_{b}$ and $\gamma_{s}$ is adopted in accordance with the diagram in Fig. 5. After analyses the coefficient values were adopted as: $\gamma_{b}=1.65$ and $\gamma_{s}=1.2$. 

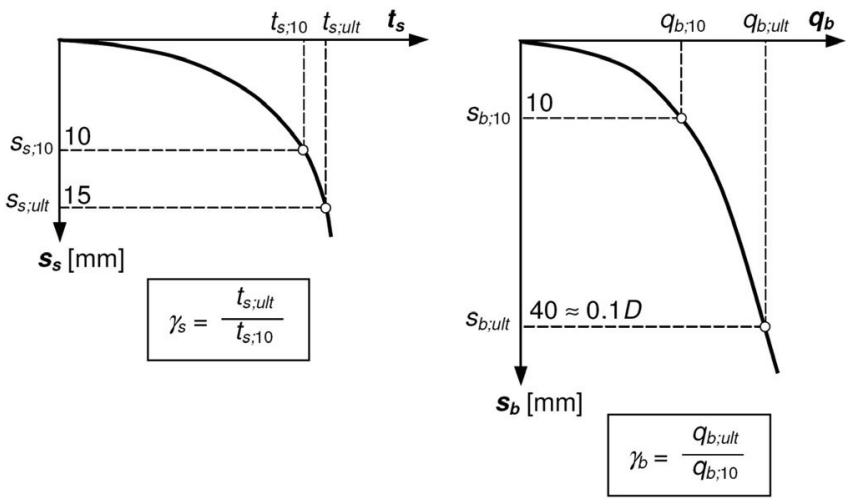

Fig. 5. A method adopted for determining partial coefficients $\gamma_{s}$ and $\gamma_{b}$

\section{Verification of calculations with real pile test}

The proposed screw displacement pile bearing capacity calculation method was verified by comparing it with the real test measurements of one example pile. The calculations were based on CPT readings carried out at the same site as the real pile. The bearing capacity values of the pile base $R_{b ; d}$ and shaft $R_{s ; d}$ as well as the total load bearing capacity $R_{c ; d}$ were defined for the lower subsoil layers, ignoring the weak upper and surface layers. Total bearing capacity $R_{c ; d}$ therefore needed to be compared with force $Q_{N}$ obtained from the test. All the calculations were carried out in accordance with the procedure described, but the correlation coefficients were taken to be $\xi_{3}=1.0$ and $\xi_{4}=1.0$ due to the fact that the CPT test was carried out exactly at the same spot as the real pile. For the comparative analysis the calculated $R_{b ; d}, R_{s ; d}$ and $R_{c ; d}$ loads were applied to graphs $Q-s$ obtained from the real test, as is shown in Fig. 6 .

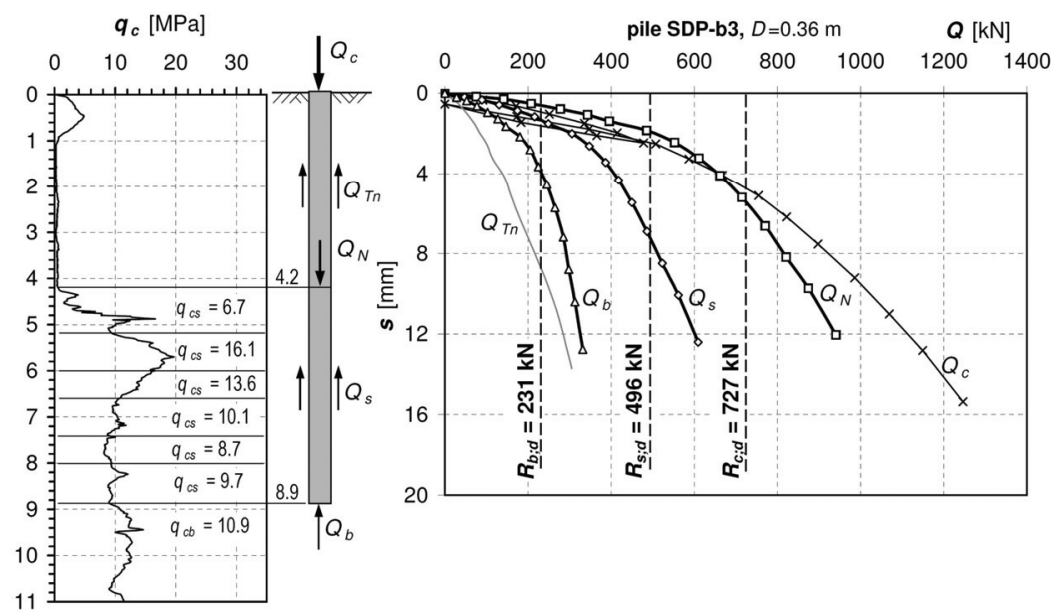

Fig. 6. Calculated pile bearing capacity compared with real pile test results (SDP-b3 pile, Pruszcz site) 
Figure 6 shows that the proposed calculation method produces pile bearing capacity values that generally correlate well with real test results. In the case of the analysed SDP-b3 pile the pile's calculated total bearing capacity $R_{c ; d}$ corresponds to force $Q_{N}$ from the test, where pile settlement is at approximately $6 \mathrm{~mm}$. More examples were analysed in paper [11]. Of these, in the decisive majority the calculated pile loads corresponded to the settlements and did not exceed the value of $10 \mathrm{~mm}$. Bearing in mind that the standard calculation procedure also includes correlation coefficients $\xi_{3}$ and $\xi_{4}$ with values higher than 1.0, one may say that the proposed method is sufficiently reliable to safely predict the bearing capacity of screw displacement piles.

\subsection{TRANSFORM FUNCTION APPROACH}

The method presented below uses transform functions $t-z$ and $q-z$, proposed by Gwizdała [4], [5]. In the computational scheme the pile is treated as an elastic rod with a constant stiffness along shaft $E A$ which is divided into a series of short elements, while the soil is modelled using a set of elasto-plastic bonds distributed along the shaft and as single elasto-plastic bond under the base. The characteristics of the bonds are nonlinear.

\section{Transform functions for screw displacement piles}

In the calculation method proposed, transform functions are determined on the basis of soil resistances $t_{s}$ and $q_{b}$ in relation to soil resistances $q_{c s}$ and $q_{c b}$ under the CPT cone. After taking into account coefficients of variation $v_{s}=0.10$ and $v_{b}=0.11$ as well as carrying out appropriate statistical analyses and transformations, transform functions for resistances $t_{s}$ and $q_{b}$ were obtained by the following formulas

$$
\begin{aligned}
& t_{s ; i}\left(s_{s}\right)=53 \cdot\left(\frac{q_{c s ; i}}{q_{r e f}}\right)^{0,25} \cdot\left(\frac{s_{s}}{z_{s ; r e f}}\right)^{0,38}[\mathrm{kPa}], \quad z_{s, r e f}=10 \mathrm{~mm}, \\
& q_{b}\left(s_{b}\right)=2475 \cdot\left(\frac{q_{c b}}{q_{r e f}}\right)^{0,16} \cdot\left(\frac{s_{b}}{z_{b ; r e f}}\right)^{0,38}[\mathrm{kPa}], \quad z_{b ; r e f}=0.1 D .
\end{aligned}
$$

As in formulas (2) and (3) reference stress $q_{\text {ref }}$ should be given the value of 1.0 $\mathrm{MPa}$. One may note that there are certain differences between formula (2) and formula (7) (in the constant and in the index of the first parenthesis). This is because formula (2) concerns ultimate resistance value $t_{s ; u l t}$ corresponding to the ultimate displacement value $s_{s ; u l t}=15 \mathrm{~mm}$, while (7) concerns resistance value $t_{s}$ with displacement $s_{s}=z_{s ; r e f}=10 \mathrm{~mm}$.

In the transformation function method one obtains from the CPT graph the pile settlement curve $Q-s$, which is divided into shaft soil resistance $Q_{s}$ and base soil 
resistance $Q_{b}$. From the thus obtained curves one can next define the pile's computational total bearing capacity $R_{c ; d}$ together with component values $R_{b ; d}$ and $R_{s ; d}$, by applying for this purpose either the settlement criterion or one of the pile's $Q-s$ curve analysis methods, such as the one recommended in Polish standard [21]. By applying the settlement criterion the pile designer may use individual permissible settlement values.

As in the classical approach, loads $R_{b ; d}$ and $R_{s ; d}$ should be reduced using coefficients $\xi_{3}$ and $\xi_{4}$ with the values set out in Table 1 . In this case, coefficients $\gamma_{b}$ and $\gamma_{s}$ should be ignored, since the $Q-s$ curve prediction as well as loads $R_{b ; d}$ and $R_{s ; d}$ are already defined to a satisfactory level of safety.

\section{Verification of method with sample test results}

The results of sample verification test are presented in Fig. 7, which include pile test $Q-s$ curves as well as corresponding curves predicted on the basis of transform function calculation methods as defined in formulas (7) and (8). The upper sandy and weak soil layers do not contribute to the pile's load bearing, but in order to define the total force curve $Q_{c}$ these layers have been assumed to have a shaft friction average value of $t_{s ; u l t}=50 \mathrm{kPa}$ for sands and $t_{s ; u l t}=25 \mathrm{kPa}$ for mud and peat.

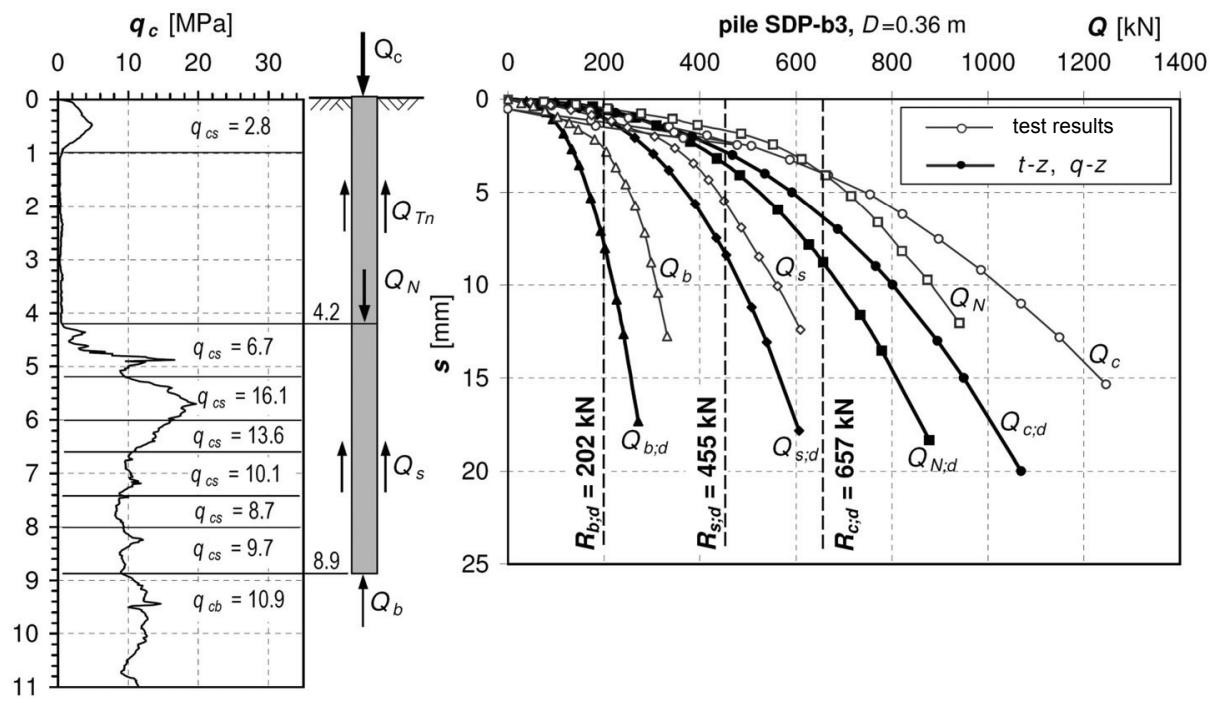

Fig. 7. Results of pile load calculation based on transform function method compared with real test results (SDP-b3 pile)

In order to define calculated loads $R_{b ; d}, R_{s ; d}$ and $R_{c ; d}$ an $s=10 \mathrm{~mm}$ settlement criterion was applied for total force $Q_{c}$. Settlements corresponding to forces $R_{b ; d}, R_{s ; d}$ and $R_{c ; d}$ are reduced by the shortening of the pile shaft. 
In comparison with the classical method results (Fig. 6), loads $R_{b ; d}, R_{s ; d}$ and $R_{c ; d}$ are approximately $10 \%$ smaller. Therefore, on the basis of this example the transform function method has turned out to be safer (or more conservative). Similar results were obtained in the other comparative analyses, most of which are included in paper [11].

The transform function method of predicting the bearing capacities of piles may be considered an alternative to conventional methods. Although it is more conservative and laborious, its advantage lies in the fact that it gives the designer greater choice in determining pile load bearing capacity. This might depend on the type of construction and especially on its sensitivity to settlements. Moreover, the transform function method provides a full nonlinear $Q-s$ pile characteristic which may next be used in static analyses of the construction to be founded on piles.

\section{CONCLUSIONS}

The methods presented in this paper for calculating the load bearing capacities of screw displacement piles on the basis of CPT results were developed empirically, using the results of field studies. For this reason these methods are reliable, as has been confirmed by comparing calculated pile load bearing results with real test results.

Furthermore, these methods comply with the general Eurocode 7 recommendations and are therefore also up-to-date from the official point of view.

Application of the above methods should, however, be restricted to piles using SDP, CMC, FDP or "Omega" augers with diameters $D$ ranging from 300 to $500 \mathrm{~mm}$ and inserted in load bearing layers comprising fine and medium coarse sands. Extending the use of these methods to other piles (e.g., Atlas and De Waal) and to other types of subsoil (silty sand or gravel) will in the future be possible after tests and analyses have been carried out, similar to those described in this paper.

The methods presented above provide net results regarding the load bearing capacity of piles, i.e., they ignore negative friction. This should be taken into account at a later stage of pile design.

One should note that the presented methods have been developed relatively recently and the versions in this paper are certainly not the final ones. In the future they are bound to be modified and corrected on the basis of analyses concerning practical use as well as subsequent pile test verifications.

The design of screw displacement piles should also be examined with regard to resistances to the auger of a pile forming in the soil. An appropriate diameter and pile length should be selected for a given piling machine torque. The issue of resistances to pile augers being screwed into the soil has also been studied in research project [11] and will be the subject of a separate publication by this author. 


\section{REFERENCES}

[1] Basu P., Prezzi M., Design and Applications of Drilled Displacement (Screw) Piles, Publication FHWA/IN/JTRP-2009/28. Joint Transportation Research Program, Indiana Department of Transportation and Purdue University, West Lafayette, Indiana, 2009, http://docs.lib.purdue.edu/cgi/ viewcontent.cgi.

[2] Bustamante M., Gianeselli L., Design of auger displacement piles from in situ tests, Proceedings of International Geotechnical Seminar on Deep Foundations on Bored and Auger Piles, BAP II. Balkema, Rotterdam, 1993, 21-34.

[3] Bustamante M., Gianeselli L., Installation parameters and capacity of screwed piles, Proceedings of International Geotechnical Seminar on Deep Foundations on Bored and Auger Piles, BAP III. Balkema, Rotterdam, 1998, 95-108.

[4] GwizdaŁA K., Analiza osiadań pali przy wykorzystaniu funkcji transformacyjnych, Zeszyty Naukowe Politechniki Gdańskiej Nr 532, Budownictwo Wodne XLI, Gdańsk, 1996.

[5] Gwizdała K., Fundamenty palowe. Tom 1: Technologie i obliczenia. Wydawnictwo Naukowe PWN, Warszawa, 2010, 297.

[6] GwiZdaŁa K., KRAsiŃSKi A., Zastosowanie przemieszczeniowych pali wkręcanych w podłożu uwarstwionym na przykladzie realizacji obiektu $w$ warunkach gruntowych delty Wisty, Inżynieria i Budownictwo, 2009, No. 3, 133-136.

[7] Holeyman A., Screw Piles - Installation and design in stiff clays, Lisse, Balkema Publishers, 2001, 323.

[8] KRAsińsKi A., Advanced field investigations of screw piles and columns, XVth Polish-French Colloquium, Gdańsk, 7-9 October 2010 and Archives of Civil Engineering, 2011, No. 1.

[9] KRASIŃSKI A., Badania terenowe przemieszczeniowych pali i kolumn wkręcanych typu SDP i SDC, Drogi i Mosty, 2011, No. 1-2.

[10] KRASIŃSKI A., Wyniki badań terenowych pali i kolumn wkręcanych, Inżynieria Morska i Geotechnika, 2011, No. 6, 510-530.

[11] KRASIŃSKI A., Nośność i praca w gruncie pali wkręcanych, Raport końcowy z projektu badawczego MNiSW nr N N506 432936, Gdańsk, grudzień 2011.

[12] Problematyka interpretacji pomiarów rozkładu sity osiowej $w$ trzonie pala podczas próbnych obciażeń statycznych, Inżynieria Morska i Geotechnika, 2012, No. 2 (in press).

[13] KrasiŃSKi A., SieŃKO R., Pomiar pionowego rozkładu sily w palu podczas testów statycznych, Mat. 56 Konf. Nauk. KILiW PAN oraz KN PZITB, Kielce-Krynica, 19-24 września 2010, 161-168.

[14] KRASIŃSKI A., SIEŃKO R., Wykorzystanie pomiaru pionowego rozkładu sity w palu do interpretacji testów statycznych, Magazyn Autostrady, 2010, No. 11, 24-28.

[15] Maertens J., Huybrechts N., Belgian screw pile technology. Design and recent developments, Swets \& Zeitlinger B.V., Lisse, The Netherlands, 2003, 372.

[16] Ne SMith W.M., Static capacity analysis of augered, pressure-injected displacement piles, Proc. of the Int. Deep Foundation Congress 2002, Geotechnical Special Publication, No. 116, Vol. 2, ASCE, 1174-1186.

[17] Van IMPE W.F., Considerations in the auger pile design, Proc. of the 1st Int. Geotechnical Seminar on Deep Foundations on Bored and Auger Piles, BAP I, Balkema, Rotterdam, 1988, 193-217.

[18] Van IMPE W.F., Influence of screw pile installation parameters on the overall pile behaviour, Workshop "Piled Foundations: full scale investigations, analysis and design", Naples, 1994.

[19] Van IMPE W.F., Screw piling: still a challenging discussion topic? Proceedings of International Geotechnical Seminar on Deep Foundations on Bored and Auger Piles, Ghent, 2003, 3-8.

[20] PN-EN 1997-1:2008. Eurokod 7. Projektowanie geotechniczne; cz. 1: Zasady ogólne.

[21] PN-83/B-02482. Fundamenty budowlane. Nośność pali i fundamentów palowych. 